Article

\title{
Residual Biomass from Dutch Riverine Areas-From Waste to Ecosystem Service
}

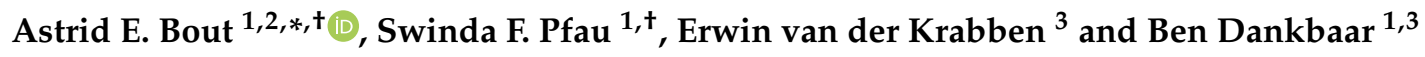 \\ 1 Institute for Science in Society, Faculty of Science, Radboud University Nijmegen, 6500 GL Nijmegen, \\ The Netherlands; Swinda.pfau@ru.nl (S.P.); B.Dankbaar@fm.ru.nl (B.D.) \\ 2 Rijkswaterstaat Oost-Nederland, Eusebiusbuitensingel 66, 6828 HZ Arnhem, The Netherlands \\ 3 Institute for Management Research, Radboud University Nijmegen, 6500 HK Nijmegen, The Netherlands; \\ e.vanderkrabben@fm.ru.nl \\ * Correspondence: astrid.bout@ru.nl \\ + Both authors contributed equally to this work.
}

Received: 11 December 2018; Accepted: 16 January 2019; Published: 18 January 2019

check for updates

\begin{abstract}
Dutch riverine areas are managed intensively to ensure the provision of various ecosystem services. Vegetation management, including pruning and mowing, produces a woody and grassy biomass as a by-product. In the past, this residual biomass has been treated as a waste product. Now there is a change of perspective; biomass is valued as a potential additional ecosystem service instead of a waste product. In this study, we explore the transition from waste to ecosystem service of residual biomass in Dutch water management organisations. We found several trends in the organisation of biomass use. There is a development away from the traditional approach of choosing the cheapest or easiest way to get rid of biomass towards exploring various uses of biomass that fulfil additional, societally relevant, functions. This trend alters the organisation of vegetation management and subsequent biomass use. Selection based on sustainable biomass uses is gaining importance, and there is a growing desire within public organisations to be able to steer towards sustainable use of residual biomass. However, there is a lack of applicable, objective ranking instruments.
\end{abstract}

Keywords: biomass as ecosystem service; residual biomass; vegetation management; water management; river ecosystem services

\section{Introduction}

In recent years, the use of biomass for various applications, such as energy and materials, has received increasing attention. The upcoming bio-economy is stimulated by various drivers, such as the need to reduce our dependence on fossil resources, the need to reduce greenhouse gas (GHG) emissions, environmental concerns and increasing demand for sustainable products, but also the expectation of a boost to rural development and other economic benefits [1]. Residual biomass is discussed as one of the important second-generation resources for bio-energy and bio-based products [2-4]. Using residues as input for new production chains transforms residual biomass from a waste into a resource. Residual biomass is increasingly considered an important resource because it potentially avoids several negative impacts associated with cultivated biomass [5]. Landscape management, for example, of roadside vegetation, municipal green and river floodplains, produces biomass as a by-product that can serve as input for the production of bio-energy and bio-based products. Large parts of The Netherlands feature riverine areas that require intensive landscape management. In the past, the residual biomass produced by vegetation management has been treated as a waste product, but now there is a change of perspective away from regarding it as waste towards valuing it as a potential additional ecosystem service. In the organisation of vegetation management, 
a shift has occurred from getting rid of biomass towards organising its sustainable use as a natural resource. In this paper, we explore the (possible) transition from waste to ecosystem service of residual biomass in Dutch water management organisations. We focus on the developments in current practice around using residual biomass from public lands and the accompanying organisational changes. Vegetation released during landscape management of public properties is a potentially important source of residual biomass. The research questions to be answered in this paper are:

- What are the current uses of residual biomass from riverine areas?

- What are the drivers for the different biomass uses?

- How is the use of biomass released during vegetation management organised and which organisational changes can be observed when biomass is considered an ecosystem service?

With this study we aim to inform landscape managing organisations, not only from the Netherlands but internationally, on possibilities to use residual biomass as an ecosystem service, providing information on biomass applications and required organisational changes. Other authors have investigated the potential of biomass from riverine landscapes as a provisioning ecosystem service [6] and compared the greenhouse gas emissions of different biomass uses quantitatively [7]. In this paper, we focus on the developments in current practices around the use of residual biomass and the accompanying organisational changes.

\section{Background}

\subsection{Bio-Economy and Residual Biomass}

Replacing fossil resources with biomass in the production of energy and materials is expected to improve the sustainability of products and production systems, but this contribution is not self-evident [1]. The production of biomass to fulfil rising demands for bio-based products requires productive land and is argued to cause both direct and indirect land use change [8-10]. Land use change can cause significant GHG emissions, and in many cases, it takes decades before initial emissions of carbon are offset by carbon savings of bio-based products [11,12].

One strategy that is often suggested to avoid the negative effects associated with land use change is the use of residual biomass [13-16]. Four types of residual biomass can be distinguished: agricultural residues, animal manure, organic waste and landscape residues [5,17]. Landscape residues may include biomass released during landscape management activities in various types of landscapes, such as forests, roadside vegetation, pastures and half-natural landscapes such as floodplains [5]. In the Netherlands, 14.5 Mton dry matter (DM) biomass was used for material and energy production in 2012 , but the demand is projected to rise to 25 to 35 Mton DM by 2030 [18]. It is estimated that around $60 \%$ of the biomass currently used are imported from outside of the Netherlands. A Dutch study on the biomass potential for gas production estimates the amount of residual biomass released during landscape management in the Netherlands (including woody landscape biomass, natural grass and roadside vegetation) at about 2 Mton DM. A part of this biomass is currently used for renewable energy production in biomass installations and as co-digestion material in biogas production. Natural grass is sometimes applied as fodder, but most landscape residues are treated in composting installations [19].

\subsection{Residual Biomass as an Ecosystem Service}

In the case of necessary vegetation management in landscapes, such as roadside vegetation and floodplains, the provision of biomass is increasingly viewed as an ecosystem service. An interesting case for this change of perception is the vegetation management in riverine areas in the Netherlands.

River systems are among the most important ecosystems in the world. The natural and semi-natural ecosystems of rivers provide ecological and socio-economic value, goods and services [20], which are now also described as ecosystem services. Numerous frameworks exist for defining and classifying ecosystem services, and there are different approaches to quantify and value them. It is a 
rapidly growing topic across various disciplines and organisations [21]. In short, ecosystems services are benefits people obtain from ecosystems. They include provisioning, regulating, cultural and supporting services [22,23]. Typical river ecosystem services are water safety, fresh water supply, flood mitigation, transport capacity, food and biomass. Ecosystem service concepts can offer a valuable approach to interpreting the links between humans and the natural environment and arguing for the conservation and restoration of natural ecosystems [24].

The Dutch river system provides ecosystem services that are of great social and economic value, including flood mitigation, navigation routes and the natural environment. Water management organisations focus on securing the provision of these ecosystem services. Large parts of the Netherlands are located in the delta of three major rivers (the Rhine, the Meuse and the Scheldt). This delta area is densely populated and especially vulnerable to peak discharges. Because the water conveyance capacity of the floodplains is lowered due to high and dense vegetation an important measure to manage flood risks is vegetation management. Since 2014, a new vegetation norm for the floodplains of the Meuse and the Rhine tributaries determines the permitted vegetation roughness per area, based on water safety considerations [25]. Vegetation has to be removed regularly to achieve the envisioned safety standard, requiring costly management measures. This has given rise to the idea of using biomass released during management measures, thereby (partly) re-paying the management costs and at the same time providing a valuable resource. The supply of residual biomass from publicly owned areas, based on yearly vegetation increments in the floodplains of the Dutch Rhine tributaries, is estimated at 370,953 tons DM of biomass, of which $87 \%$ are grassy biomass. This is equivalent to an estimated 353 Tera Joule of heat produced from woody biomass and 15 million $\mathrm{m}^{3}$ of green gas from grassy biomass [7].

\subsection{Sustainability Ambitions and Instruments}

An increasing number of countries worldwide are pursuing explicit political strategies to expand and promote the bio-economy [26]. In the Netherlands, strategies are being developed to switch from fossil to green resources to tackle the challenge of resource dependencies and climate change. In the absence of large quantities of biomass resources, focus in the Netherlands lies on product development and the (chemical) processing industry to drive the transition, increasing the efficiency of biomass use and waste stream recycling [26,27].

The Netherlands has set ambitious goals for the bio-economy at the national level, but these do not specifically include the use of residual biomass from landscape management. However, a change in the perception of landscape residues can be observed. Increasingly, public organisations, including water management organisations, engage in projects that consider residual biomass as a useful, natural resource instead of a waste product. Traditional objectives of water management organisations, such as ensuring flood safety, realising appropriate natural environment management and creating a healthy living environment, are combined with the goal of using biomass as an ecosystem service. The provision of biomass then becomes a by-product of river management and water management organisations are stimulated to enter a new market.

One important operational barrier for reusing residual biomass is manifested in Dutch legislation. Under Dutch law, residual products, such as biomass from landscape management, are waste products. Their transportation, storage and use underlie strict environmental laws and regulations. To reuse residual biomass from landscape management for new products, it must undergo waste treatment (usually composting), after which its status is changed from a waste product to a resource.

For the execution of vegetation management, public organisations have several instruments that can help to steer towards sustainability. In general, three options to organise vegetation management can be considered: Water management organisations can execute the management themselves, they can enter a tendering procedure and choose a market party for the execution based on the best price only, or they can include additional criteria, other than price, in the tendering procedure. To steer towards sustainability in a tendering procedure, public organisations can either formulate 
requirements up front or leave the specific approach towards increased sustainability up to the market parties, including evaluation criteria for sustainability in the selection procedure. The Dutch ground-, road- and water engineering sector developed two instruments to evaluate sustainability in tenders: the " $\mathrm{CO}_{2}$ performance ladder", to stimulate $\mathrm{CO}_{2}$ awareness and "DuboCalc", based on Life-cycle assessment (LCA). Both instruments enable a sustainability rating of the engineering and execution of works, the use of materials, energy and the disposal of waste (http:/ /www.duurzaamgww.nl). However, sustainable use of residual resources released during vegetation management is not included. In the upcoming bio-economy, this is a new phenomenon, and it appears that no formal evaluation instruments have yet been developed. This corresponds to the lack of specific goals for the use of residual biomass from landscape management in the different National and regional policy documents from water management organisations.

\section{Methods}

We researched the use of biomass in current water management practices in three types of organisations involved in water management: Rijkswaterstaat, the executive part of the Dutch Ministry of Infrastructure and Water Management, the Dutch State Forestry Service and Dutch water boards. In this study, we are only considering biomass released from public lands, owned by one of these organisations.

Rijkswaterstaat is responsible for the design, construction, management and maintenance of the main infrastructure facilities in the Netherlands. This includes the main roads, the main waterway network and water systems. Rijkswaterstaat owns and manages $2137 \mathrm{~km}$ of canals and rivers and the strip of land along the river beds. The main goal for the execution of vegetation management by Rijkswaterstaat is to reduce the vegetation roughness to secure the water discharge capacity and reduce flood risk.

The Dutch State Forestry Service is a public enterprise commissioned by the Dutch government to strengthen the position of the natural environment in the Netherlands. They are manager and owner of 265,000 ha of forest and national parks across the Netherlands. Their main goal is to conserve, develop and sustain the natural environment, but also to contribute to the realisation of national priorities, which include wood and biomass production and water safety strategies along the coast and large river systems [28]. The State Forestry Service is responsible for the vegetation management on their grounds in the floodplains.

The Dutch water boards are regional governmental bodies charged with managing regional water systems including water levels, water barriers, water quality and sewage treatment. There are 21 water boards in the Netherlands, and together they manage a total $235,000 \mathrm{~km}$ of ditches and small rivers (https://dutchwaterauthorities.com/about-us/). They are responsible for the vegetation management in these water systems, aiming at regulating water levels and water quality.

We contacted various people engaged in vegetation management at Rijkswaterstaat, the State Forestry Service and at all water boards in the Netherlands. We created a database of vegetation management practices in these organisations, containing details about the organisation of vegetation management and biomass use. We gathered information from 19 of the 21 water boards, the three relevant units of Rijkswaterstaat and five relevant regional units of the State Forestry Service, which feature riverine areas in their management areas. We then analysed the organisational arrangements of vegetation management in these organisations, which are described in Section 4.2. To enable a closer look at both the organisation and the drivers behind biomass use, we studied exemplary cases from each organisational arrangement and, where possible, each (type of) river management organisation. For a total of 13 cases, we conducted semi-structured interviews with employees responsible for vegetation management within their organisation. As is appropriate for open-ended, explorative questions, we purposefully selected interviewees that would help to understand the problem and research questions at hand [29]. The interviewees represent the medium or lower management within their organisations. We chose them because we valued their familiarity with current vegetation 
management practices. Semi-structured interviews were chosen to ensure that the same topics were addressed in each interview. At the same time, this approach leaves room for individual conversations, where opinions and experiences of interviewees can be addressed. The interview topics were based on observations from the above-described database of vegetation management practices, and biomass uses developed for this study. We developed an interview guide with primary and follow-up questions to structure the interviews and ensure that all topics were addressed. During the interviews we discussed four main topics:

1. Current execution of vegetation management.

2. Organisation of and responsibility for vegetation management.

3. Current use of biomass released during vegetation management and related drivers and decision-making processes.

4. Visions and ambitions concerning biomass use of the water management organisation.

All interviewees were informed about the interview topics in advance to allow them to prepare themselves. The interviews were recorded and transcribed. The transcripts were then analysed in line with a thematic analysis approach. We used the qualitative data analysis (QDA) software package ATLAS.ti (version 7) to identify common themes in the interviews, coding the transcripts in several steps. During analysis, the interviewees were regarded as stakeholders with detailed knowledge of and personal experience with vegetation management and biomass use in current practice. Their opinions are not necessarily representative for the vision of their entire organisation, but they were regarded as knowledgeable on their organisation's strategy.

To broaden our insights and hear more about higher management perspectives, we also conducted three interviews with managers of working groups or departments concerned with biomass use positioned close to the top management of the three organisations. In these interviews, we focused on organisational visions and ambitions and goals for biomass use in the future. An overview of the interviews is shown in Table 1.

Table 1. Overview of interviews. One interview was conducted per organisation part. If an interview delivered sufficient information about multiple organisational arrangements, it is listed under each arrangement.

\begin{tabular}{|c|c|c|}
\hline Organisational Arrangement & Organisation Type & Organisation/Department \\
\hline \multirow{4}{*}{ Tenancy } & Water board & Rijn en IJssel \\
\hline & Rijkswaterstaat & Tenancy contracts \\
\hline & State Forestry Service & Maasheggen \\
\hline & State Forestry Service & Gelderse Poort \\
\hline \multirow[t]{3}{*}{ Passed to adjoining landowner } & Water board & Brabantse Delta \\
\hline & Water board & Scheldestromen \\
\hline & Water board & Aa en Maas \\
\hline \multirow[t]{4}{*}{ Passed to contractor } & Water board & Limburg \\
\hline & Water board & Vallei en Veluwe \\
\hline & Rijkswaterstaat & Standard maintenance contracts \\
\hline & State Forestry Service & Maasheggen \\
\hline \multirow[t]{3}{*}{ Ranked tendering } & Water board & Schieland en de Krimpenerwaard \\
\hline & Water board & Aa en Maas \\
\hline & Rijkswaterstaat & New contract region IJssel \\
\hline \multirow[t]{2}{*}{ Pre-determined use } & Water board & Brabantse Delta \\
\hline & Water board & De Stichtse Rijnlanden \\
\hline \multirow[t]{2}{*}{ In-house } & Water board & Brabantse Delta \\
\hline & Water board & Vallei en Veluwe \\
\hline \multirow[t]{3}{*}{ Additional interviews centralised groups } & State Forestry Service & Manager product group biomass \\
\hline & Rijkswaterstaat & Manager business unit natural capital \\
\hline & Water board & $\begin{array}{l}\text { Chairman working group biomass of the "energy-and } \\
\text { resources factory" initiative of the Dutch water boards }\end{array}$ \\
\hline
\end{tabular}




\section{Results}

In this section, we present the results of our analysis of both the database and the interviews. First, we will describe the current uses of residual biomass from riverine areas and briefly discuss the drivers for the different uses. Subsequently, we describe the different organisational arrangements we identified and discuss the relationship between the biomass uses and corresponding organisational arrangement. Finally, we will present some notable emerging issues that arose while discussing trends and expectations of future values and markets for residual biomass from landscape management in the interviews with both practitioners and managers.

\subsection{Current Biomass Uses}

From the 13 semi-structured interviews with practitioners responsible for vegetation management, we identified 12 different biomass uses (Table 2). We distinguish between woody (tree trunks, branch wood, wood clippings) and grassy biomass (grass/herbs from dykes, ditches and floodplains).

Table 2. Residual biomass uses in current water management practice.

\begin{tabular}{|c|c|c|}
\hline & Biomass Use & Description \\
\hline \multirow{2}{*}{ Woody } & Woodchips & Processing of branch wood into woodchips for biomass boilers \\
\hline & Construction wood & Harvested trees of sufficient quality processed by the wood industry \\
\hline \multirow{9}{*}{ Grassy } & Biogas & Co-fermentation of grassy biomass \\
\hline & Grass pellets & Compression of grassy biomass into pellets used in biomass boilers \\
\hline & Leave at site & Biomass left at the maintenance site or spread out in direct vicinity \\
\hline & Local soil application & $\begin{array}{l}\text { Local use of grassy biomass on agricultural land, where it is mixed with } \\
\text { soil aiming at an improved soil organic matter (SOM) content }\end{array}$ \\
\hline & Compost & $\begin{array}{l}\text { Industrial composting of biomass, producing compost for applications } \\
\text { in agriculture and as peat replacement in soil production }\end{array}$ \\
\hline & Grass fibre & $\begin{array}{l}\text { Processing of grassy biomass into fibres for fibre board or paper and } \\
\text { carton production }\end{array}$ \\
\hline & Grazing & Grazing of grassy biomass \\
\hline & Hay & Processing of grassy biomass into hay for animal feed \\
\hline & Feed organic agriculture & Processing of grassy biomass into animal feed for organic agriculture \\
\hline
\end{tabular}

Both woody and grassy biomass were used to produce energy as either woodchips, biogas or grass pellets. Most interviewees conveyed the opinion that energy is considered a low-value application. Some stated that when biomass is used for energy, it must at least have a positive impact on the $\mathrm{CO}_{2}$-balance of the organisation, which is not always clear or known. Only one interviewee had a positive feeling about energy uses, stating he believed it is better to use the energy from residual biomass than from non-renewable sources, based on $\mathrm{CO}_{2}$ emissions.

Although harvesting of trees seldom occurs in the vegetation management of water management organisations, trees of sufficient quality are sometimes used in the construction wood industry. The market for construction wood is well developed and selling wood to the wood industry is a common practice that also generates some revenues. Grassy biomass is sometimes also used as a source for construction material. The grass fibres are used for fibre boards and paper- or cardboard production. These techniques are emergent and sometimes still have a pilot status. Water management organisations consciously chose to participate in such pilots, because they want to explore the possibilities of residual biomass and identify valuable uses.

Water boards, especially, often leave grassy biomass from ditch banks and channels at the maintenance site or in the direct vicinity (at the top of the slope). The main driver is to avoid transport costs and also possible damage to land, roads and dykes as a result of transport. In some cases, it is practically impossible to remove the biomass, because there is a lack of space for machinery. In other cases, the biomass is passed to the adjoining landowner, who has to remove it and usually spreads it 
out over adjoining land. Passing biomass to the adjoining landowner is also seen as traditional within Dutch water boards. 'Leave at site' is often seen as a 'default' option, because it is the cheapest solution with the least handling. It is, however, not always desirable, since leaving the biomass at site causes mineral deposition, which is not always in line with environmental goals and can provide a substrate for weeds like thistles and nettles, which is undesirable for adjoining farmers. In many situations, especially in flood-prone areas along the major rivers, biomass may not be left behind due to safety considerations, as it may reduce water discharge capacities.

Whenever biomass cannot be left behind, composting is the default option. It is described as one of the more traditional biomass uses, and almost all of the interviewees see composting as one of the least desirable applications. In the Netherlands, composting is a waste treatment, which means that a gate-fee has to be paid when depositing the material at the composter. On top of the gate-fee, there are also transport costs, which make composting an expensive biomass use.

Local soil application of biomass is receiving growing interest and is regarded as an alternative for composting by some interviewees. The grassy biomass is mixed with agricultural soil aiming at improving the soil organic matter (SOM) content. Before ploughing it into the ground, the biomass can undergo different pre-treatments with the objective to make the organic content more easily available for the soil. One reason to choose local soil application is the relationship with farmers. Farmers are looking for ways to improve the organic matter content of their land and, therefore, approach water management organisations for their residual biomass. Local soil application is also perceived as a high-value biomass use by most interviewees because the application is local and assumed to improve agricultural production. It is also expected to improve the water retention capacity of the soil, which can contribute to the water management goals of the organisations. Finally, local soil application is cheap, because transport and deposition costs for composting are avoided.

Grassy residual biomass is used to feed livestock, either in the form of hay or by grazing. The use of residual biomass for feed is considered valuable, especially when it would otherwise be treated as waste. It can also generate some revenues. However, it is not always possible to produce hay due to weather conditions. When the quality is insufficient, the biomass is brought to the composter. A special category for feed is hay and grazing for organic agriculture. Organic farming is described as more valuable than traditional farming by some interviewees. Floodplains are particularly interesting for organic farmers because fertilisers and pesticides are prohibited on these sites.

In many cases, interviewees referred to the relative value of applications as a driver for the choice of biomass uses. Sometimes this was described rather vaguely as a feeling that certain uses are societally more or less useful, in other cases, concepts for prioritising different applications were cited: Either the so-called 'Lansink ladder' or the biomass value pyramid, both well-known concepts in the Dutch bio-economy debate were referred to. The Lansink ladder is a standard in waste management, ranking options such as recycling, energy recovery and disposal from favourable to unfavourable. The value pyramid is a similar concept, but specific to the bio-economy. It ranks different biomass applications and sectors, for example, food, chemicals and fuels in terms of added value. Both of these concepts are interpreted by interviewees to prioritise applications for food production or material reuse of biomass over energy applications and composting.

\subsection{Organisational Arrangements}

From our database of vegetation management practices, we identified six different organisational arrangements based on the type of contract underlying vegetation management and on who is deciding about the biomass use (Table 3 ). 
Table 3. Organisational arrangements.

\begin{tabular}{ccc}
\hline Organisational Arrangement & Contracting for Vegetation Management & Decision about Biomass Use \\
\hline Tenancy & Tenancy & Tenant \\
\hline Passed to adjoining landowner & In-house or tendering & Adjoining landowner \\
\hline Passed to contractor & Tendering & Contractor \\
\hline Ranked tendering & Tendering & $\begin{array}{c}\text { In-house ranking procedure } \\
\text { during tendering }\end{array}$ \\
\hline Pre-determined use & Tendering or Tenancy & In-house \\
\hline In-house & In-house & In-house
\end{tabular}

Tenancy: Use of land, including obligations for vegetation management, are offered via a tendering procedure. Tenants have to submit a bid for a certain piece of land. Tenders include guidelines and requirements for the tenant, but the tenant decides how biomass is used.

Passed to adjoining landowner: Most Dutch water boards traditionally apply a so-called 'reception obligation', which means that landowners adjoining to the managed site are obliged to receive and handle the residual biomass. This way, water boards do not have to handle transport or disposal of biomass. The adjoining landowner determines the biomass use.

Passed to contractor: Vegetation management is executed by a contractor who is selected via tendering. The ownership of the biomass is passed to the contractor, and the contractor decides how the biomass is used. No requirements regarding the biomass use are specified, other than that it has to be removed and treated according to the law.

Ranked tendering: Similar to the arrangement 'passed to contractor', the vegetation management is executed by a contractor who is selected via tendering. In the description of the tender requirements regarding biomass use are specified. During the selection procedure, the tenderer can score points or a fictitious discount on the price he offers for the service, based on the biomass use he proposes. Requirements are, for example, 'for every $10 \%$ of the biomass which is used more sustainably the tenderer is rewarded with a fictitious discount' or 'come up with a plan for improvement and investment proposals regarding vegetation management'. The tenderer with the best overall score on (discounted) price or points wins the procedure.

Pre-determined use: The vegetation management is executed by a contractor selected via tendering. The use of the biomass is pre-determined, which means that the water management organisation prescribes the use of the biomass in the contract, based on previous arrangements with a biomass user.

In-house: Both the execution and the decision making on the biomass use is done by the water management organisation.

\subsection{Relation between Biomass Uses and Organisational Arrangements}

To see whether certain organisational arrangements trigger specific biomass uses (or the other way around) we looked at the different biomass uses per organisational arrangement. For each interview, we recorded what kind of biomass use occurred and to which organisational arrangement(s) it was linked. Table 4 presents the biomass use per organisational arrangement as a percentage of the total number of uses mentioned for each organisational arrangement. The organisational arrangement of tenancy mainly co-occurs with the biomass uses hay and grazing, while 'passed to adjoining landowner' is only linked to the biomass uses 'leave at site' and 'local soil application'. The largest variety in biomass uses is seen with the organisational arrangements 'passed to contractor' and 'ranked tendering'. 'Pre-determined use', on the other hand, is not linked to many different biomass uses. 
Table 4. Relation organisational arrangement and biomass use. Biomass use per organisational arrangement is presented as a percentage of the total number of uses mentioned for each organisational arrangement.

\begin{tabular}{|c|c|c|c|c|c|c|c|}
\hline \multirow[b]{2}{*}{$\begin{array}{l}\text { Biomass } \\
\text { Type }\end{array}$} & \multirow[b]{2}{*}{ Use } & \multicolumn{6}{|c|}{ Organisational Arrangement } \\
\hline & & Tenancy & $\begin{array}{c}\text { Passed to Adjoining } \\
\text { Landowner }\end{array}$ & $\begin{array}{l}\text { Passed to } \\
\text { Contractor }\end{array}$ & $\begin{array}{l}\text { Ranked } \\
\text { Tendering }\end{array}$ & $\begin{array}{l}\text { Pre-Determined } \\
\text { Use }\end{array}$ & In-House \\
\hline \multirow{2}{*}{ Woody } & Woodchips & 0 & 0 & 18 & 0 & 0 & 11 \\
\hline & Construction wood & 0 & 0 & 5 & 0 & 0 & 0 \\
\hline \multirow{9}{*}{ Grassy } & Leave at site & 9 & 60 & 14 & 0 & 0 & 33 \\
\hline & Compost & 9 & 0 & 32 & 27 & 33 & 22 \\
\hline & Grazing & 36 & 0 & 0 & 9 & 0 & 0 \\
\hline & Hay & 36 & 0 & 9 & 9 & 33 & 11 \\
\hline & Local soil application & 9 & 40 & 14 & 0 & 33 & 22 \\
\hline & Biogas & 0 & 0 & 5 & 18 & 0 & 0 \\
\hline & Grass pellets & 0 & 0 & 0 & 9 & 0 & 0 \\
\hline & Grass fibre & 0 & 0 & 5 & 18 & 0 & 0 \\
\hline & Feed organic agriculture & 0 & 0 & 0 & 9 & 0 & 0 \\
\hline Total & & $100 \%$ & $100 \%$ & $100 \%$ & $100 \%$ & $100 \%$ & $100 \%$ \\
\hline
\end{tabular}

\subsection{Biomass Uses: Trends, Values and Market}

Discussing trends and expectations of future values and markets for residual biomass from landscape management with the interviewees revealed some interesting issues. Some interviewees had never thought about the potential and possibilities of residual biomass and preferably would leave the responsibility to the contractor. Others noticed that residual biomass from landscape management is 'hot' and that they are urged by their higher management to 'do something' with biomass. Almost all interviewees pointed out that financial aspects are not the only thing to consider when valuing the use of biomass, but that social, ecological and environmental values are also highly important. A dilemma was felt between creating income and creating societal or environmental values and some questioned if it was possible at all to responsibly harvest biomass from ecologically valuable areas. Most of the interviewees saw societally responsible use of biomass as a prerequisite and stated that higher costs are justifiable if the biomass use contributes to other goals or create other values.

Composting was often described as the least valuable biomass use, and most organisations are looking for 'more sustainable uses than composting' although 'more sustainable' was not specified further. In general, local use is considered of high value and export of biomass away from the vicinity of the management site, for example, for materials or energy, is perceived as less desirable. However, if a contractor can profit from selling biomass, most organisations expect that this will be reflected in the price they pay for the execution of the vegetation management, stimulated by competition between bidding contractors. Organisations sometimes also choose not to interfere when contractors find new ways to market biomass because they prefer new biomass uses over composting. Some contractors are now trying to develop new revenue models for the use of residual biomass from landscape management.

Many interviewees argued that it is unclear what the possibilities and values of residual biomass are and, therefore, they participate in pilots for the development of new techniques. They investigate, for example, whether alternative mowing regimes can improve the quality of the biomass (less sand, dryer) to make it more suitable for specific new biomass applications. Some organisations are willing to invest in these pilots, even though the cost may be higher than the initial financial benefits. The choice to participate in a pilot is not based on calculations or $\mathrm{CO}_{2}$-balance, but on a general feeling of a useful direction.

Expecting the value of biomass to increase, Rijkswaterstaat recently changed the ownership over residual biomass in all forthcoming tendering procedures. Formerly, the ownership passed from Rijkswaterstaat to the contractors, but now it remains with Rijkswaterstaat. This way they 
can decide what to do with the biomass without interference by the contractor. One of the water boards has prescribed that all biomass must go to a central point so that it can keep track of the amount of biomass released. This can help them to participate in new business cases. Most water management organisations do not have official ambitions or goals regarding biomass use, but some have sustainability goals, which in some cases may also apply to biomass use.

\section{Discussion}

In this paper, we described how water management organisations organise the use of residual biomass, a by-product of their vegetation management activities, and what their expectations are regarding its use in the future. Residual biomass, formerly seen as a waste product, is now increasingly viewed as a potential resource. We found several trends in the organisation of biomass use. In Section 4.1, we described the various uses of biomass that are currently realised. We found that there is a development away from the traditional approach of choosing the cheapest or easiest way to get rid of biomass towards exploring various uses of biomass that fulfil additional, societally relevant, functions. This trend alters the organisation of vegetation management and subsequent biomass use: selection of sustainable biomass uses is gaining importance in the choice of organisational arrangements. Both the water management organisations themselves and the contractors and market parties involved can play a role in this. In Section 4.3 we showed that the more traditional organisational arrangements of 'tenancy' and 'passed to adjoining landowner' result mostly in the more traditional biomass uses that one would expect. The organisational arrangements that transfer the responsibility for biomass use to contracted market parties deliver a greater variety of biomass uses, including some newer applications relevant for the upcoming bio-economy, such as bio-energy (e.g., biogas, woodchips) and bio-based products (e.g., grass fibres). Greater control of the water management organisations over biomass use, as in organisational arrangement 'pre-determined use' and 'in-house', does not result in the same variety, but we did encounter that some organisations use these arrangements to participate in pilots, experimenting with newer biomass uses that are not ready for the market yet (see Section 4.4). It appears that a new market is developing around the use of residual biomass from landscape management, and both contractors and water management organisations are reacting to this, for example, by changing ownership arrangements in tendering (see Section 4.4). While in some cases traditional organisational arrangements and biomass uses prevail, in others a phase of trial and error seems to develop, exploring the potential of this new market. It would be interesting to research this further by comparing the development with other newly developing markets, for example, of other natural resources or other ecosystem services.

Methods of public organisations to steer contracted works towards more sustainability until now focused on the execution of works and the use of materials (see Section 4.2). In this study, we found that recently new instruments are being developed and applied, in which the sustainable use of residual biomass is being promoted specifically. In all three types of water management organisations, we saw examples of the organisational arrangement 'ranked tendering', where the use of biomass is one of the ranking criteria. The methods to rank different uses in the tendering procedure, however, differed substantially. In all interviews addressing this organisational arrangement, it was expressed that formal, objective comparison of biomass uses was difficult due to a lack of ranking methods. Ranking was instead based on innovations, estimated position in the biomass value pyramid or a general feeling of societal relevance. In contrast to the execution of work and use of materials, the ranking of sustainability of resource and by-product uses is not yet institutionalised and there is no evaluation system in place, resulting in a trial and error approach and uncertainty.

There is currently a lack of consensus in the scientific community about the sustainability of the bio-economy in general, and even more so on the best way to use biomass. On the one hand, it is argued that bio-energy is important to reach renewable energy goals and mitigate climate change [30]. On the other hand, bio-energy is criticised as being inefficient in actually reducing carbon emissions and competing with other land uses; biomass should, therefore, only be applied for biomass material 
uses [31]. This lack of scientific consensus may explain why applicable, objective ranking instruments in public tendering are missing, and no objective ranking instruments were applied in the public tendering procedures observed in this study. Ranking criteria are, however, gaining importance, since there is a growing desire within public organisations to be able to steer towards sustainable use of residual biomass.

The lack of ranking criteria leaves room for interpretation, revealing a dilemma between evaluating based on function or costs. Different biomass uses have differing functions and societal relevance. In various interviews, it was mentioned that bio-energy is seen as a low-value application of biomass. Bio-energy was consequently often excluded or kept to a minimum in the choice of biomass uses. However, in practice, this was only true for bio-energy production from grassy biomass. In the case of woody biomass, the use as woodchips for energy production was the most chosen biomass use, because, in contrast to grassy biomass, there is a market for woodchips for energy and this biomass use is therefore economically attractive. A similar pattern emerged for biomass uses for soil improvement: many interviewees elaborated on the importance of improving soil quality in agricultural areas, both to ensure yields in the future and to achieve a greater water retention capacity in the soil surrounding water systems. But while compost is a classic and proven product to improve soil quality, composting is seen as a very low-value biomass use, mainly because it is depicted as simply a waste treatment method. Local soil application, aiming at using biomass as a SOM improvement on fields directly, is preferred by almost all interviewees. However, the potential of this direct application in actually increasing SOM is not proven. While composting and local soil application are assumed to fulfil the same function, composting is argued to be of lower value. Composting is currently the most expensive biomass use for water management organisations, while with local soil application the biomass can now be deposited for free or even generate some income.

In both examples of bio-energy application and soil improvement, the value of a biomass use is in the practical evaluation mixed with costs, and the costs are in the end the most influential factor, even though the main argumentation is based on the value of the biomass use. This makes the evaluation of sustainable biomass uses rather unclear and subject to change with developing markets and technologies. The consideration of bio-energy as a low-value product may also be related to cultural values. Prioritisation concepts such as the biomass value pyramid are particularly popular in the Netherlands, while internationally other values might prevail, for example, prioritising bio-energy for its potential to achieve $\mathrm{CO}_{2}$ benefits by replacing conventional energy sources. Since there is no scientific consensus on the most sustainable use of biomass, it is not possible to give advice on the one best biomass use at this point; further research is required to develop ranking criteria for the choice of biomass uses. It is recommended to promote this research to enable a choice of sustainable applications and avoid the confusion of societal value and cost. If biomass applications that are now not preferred options due to higher costs turn out to be of greater societal value, efforts could be undertaken to make these uses more attractive.

The changing organisation of biomass use observed in this study does not necessarily result in economic advantages for water management organisations. There are various drivers for the engagement in residual biomass use, as described in Section 4.1. Saving or earning money is, therefore, not necessarily the most important reason for public organisations to think differently about residual biomass. There is also growing attention for the societal relevance of sustainable use of resources and the wish to contribute to societal goals. A preference for 'valuable' use of biomass was expressed by many of the interviewees, but interpretations of value varied and were often subjective, similar to the ranking criteria in 'ranked tendering'. Lack of ranking criteria may influence the choice of biomass uses, but it is unclear whether it also influences the choice of organisational arrangement. In some cases, it was mentioned that the choice of biomass use was left to contractors, trusting that market mechanisms would result in societally relevant use.

Even though financial considerations appeared to be not the only or most important driver to think differently about residual biomass use, we did find that some organisations expect the value of biomass 
to increase in the future. In the developing bio-economy, they expect that demand for biomass will rise and possibilities to use lower-value residues will be developed further. This also results in alterations of the organisation of vegetation management: as described in Section 4.4, Rijkswaterstaat now remains the owner of residual biomass instead of passing it on to the contractor. This expectation of a higher value of biomass may, however, be misleading in the long term. If the demand for biomass, and, therefore, its value, increases in the future, provision of biomass will become more lucrative. Biomass from riverine landscapes will then have to compete with biomass from specific production grounds. Water management organisations will probably not be able to compete on price, because biomass harvesting is much less efficient in floodplains and along ditches than on fields or in production forests. In their consideration of vegetation management, water management organisations should, therefore, keep in mind that residual biomass provision is only a by-product, while the main product is a well-managed landscape, fulfilling the main water-related goals of the organisations. Exploiting biomass as an additional ecosystem service may contribute to reducing management costs, but it is unlikely that significant revenues will be generated in the future. Water management organisations, therefore, should not focus on biomass production and expect to achieve more than a reduction of costs. Rather, they should strive for sustainable and societally responsible use of biomass as a by-product, in accordance with their role as public organisations.

\section{Conclusions}

Residual biomass from landscape management is increasingly viewed as a promising, sustainable resource for the international bio-economy. The Netherlands is a useful case study to analyse the use of residual biomass that was formerly considered a waste product. In this study, we showed that useful applications of residual biomass are already current practice. The consideration of biomass as an ecosystem service instead of a waste product is a useful frame to realise societal value. A new market appears to develop around residual biomass use, and this study showed that water management organisations are reacting to this by developing new tendering procedures, changing biomass ownership and engaging in pilot projects to explore new applications. Financial considerations, however, appear not to be the only driver to reconsider the use of residual biomass. Using biomass for societally relevant or 'valuable' applications is another important driver, influencing the choice of biomass applications.

Residual biomass from landscape management is currently used for multiple applications, including both energy and material applications. No formal, objective evaluation methods are applied or available. More scientific research is needed supporting the development of objective methods to compare the sustainability merits of different biomass applications. Currently, the lack of ranking criteria results in a trial and error approach and uncertainty. Using prioritisation concepts such as the biomass value pyramid as orientation for evaluating uses results in a preference for material uses over bioenergy. Furthermore, in practice, considerations of societal value of biomass use are mixed with costs. Water management organisations should strive for sustainable and societally responsible use of biomass as a by-product of landscape management. Ranking criteria to prioritise between different biomass uses, based on both general contributions to sustainability, but also local needs and opportunities for biomass uses, such as depleted soils or demand for renewable energy provision, should be developed to help with these efforts.

Landscape management practices should be adapted to make optimal use of residual biomass as an ecosystem service. Public organisations can play an important role in the development of residual biomass use in the Netherlands and internationally. They are generally in charge of landscape management and have a responsibility to use ecosystem services sustainably. Changing tendering procedures to include sustainability evaluation of biomass harvest and biomass use can stimulate creative solutions to collect biomass, instead of leaving it behind, and finding feasible, societally relevant applications. Vegetation management practice can furthermore be optimised to enable efficient residual biomass harvesting for sustainable applications, for example, combining mowing and 
pruning activities with direct biomass collection. Residual biomass use can also be promoted by pilots and innovation, to find new efficient applications for residual biomass. However, water management organisations should keep in mind that residual biomass is only a by-product of a well-managed landscape and biomass harvest should not be the main goal of vegetation management.

Author Contributions: A.B. and S.P. contributed equally to this research and the resulting paper. Conceptualization, A.B. and S.P.; Data curation, A.B. and S.P.; Formal analysis, A.B. and S.P.; Investigation, A.B. and S.P.; Methodology, A.B. and S.P.; Supervision, B.D. and E. van der K.; Validation, A.B. and S.P.; Writing-original draft, A.B. and S.P.; Writing-review and editing, A.B., S.P., B.D. and E. van der K.

Funding: This research is part of the research program RiverCare, supported by the Dutch Technology Foundation STW, which is part of the Netherlands Organization for Scientific Research (NWO), and which is partly funded by the Ministry of Economic Affairs under grant number P12-14 (Perspective Programme). The funding agencies were not involved in the design, execution and reporting of this study.

Acknowledgments: We are thankful to the interviewees who agreed to participate in this study. We are also thankful to Emiel Derksen for his help in establishing the initial database of vegetation management practices and setting up interviews. We are grateful to four anonymous reviewers for their comments on a previous version.

Conflicts of Interest: The authors declare no conflict of interest.

\section{References}

1. Pfau, S.; Hagens, J.; Dankbaar, B.; Smits, A. Visions of Sustainability in Bioeconomy Research. Sustainability 2014, 6, 1222-1249. [CrossRef]

2. Yazan, D.M.; van Duren, I.; Mes, M.; Kersten, S.; Clancy, J.; Zijm, H. Design of sustainable second-generation biomass supply chains. Biomass Bioenergy 2016, 94, 173-186. [CrossRef]

3. Naik, S.N.; Goud, V.V.; Rout, P.K.; Dalai, A.K. Production of first and second generation biofuels: A comprehensive review. Renew. Sustain. Energy Rev. 2010, 14, 578-597. [CrossRef]

4. Chandra, R.; Takeuchi, H.; Hasegawa, T. Methane production from lignocellulosic agricultural crop wastes: A review in context to second generation of biofuel production. Renew. Sustain. Energy Rev. 2012, 16, 1462-1476. [CrossRef]

5. Pfau, S.F. Residual Biomass: A Silver Bullet to Ensure a Sustainable Bioeconomy? In The European Conference on Sustainability, Energy \& the Environment 2015: Official Conference Proceedings; ECSEE2015: Brighton, UK, 2015; pp. 295-312.

6. Searchinger, T.; Heimlich, R.; Houghton, R.A.; Dong, F.; Elobeid, A.; Fabiosa, J.; Tokgoz, S.; Hayes, D.; $\mathrm{Yu}, \mathrm{T}$.-H. Use of U.S. Croplands for Biofuels Increases Greenhouse Gases Through Emissions from Land-Use Change. Science 2008, 319, 1238-1240. [CrossRef] [PubMed]

7. Plevin, R.J.; O’Hare, M.; Jones, A.D.; Torn, M.S.; Gibbs, H.K. Greenhouse gas emissions from biofuels' indirect land use change are uncertain but may be much greater than previously estimated. Environ. Sci. Technol. 2010, 44, 8015-8021. [CrossRef] [PubMed]

8. Wicke, B.; Verweij, P.; van Meijl, H.; van Vuuren, D.P.; Faaij, A.P. Indirect land use change: Review of existing models and strategies for mitigation. Biofuels 2012,3, 87-100. [CrossRef]

9. Fargione, J.; Hill, J.; Tilman, D.; Polasky, S.; Hawthorne, P. Land Clearing and the Biofuel Carbon Debt. Science 2008, 319, 1235-1238. [CrossRef]

10. Lamers, P.; Junginger, M. The 'debt' is in the detail: A synthesis of recent temporal forest carbon analyses on woody biomass. Biofuels Bioprod. Biorefin. 2013, 7, 373-385. [CrossRef]

11. Hatti-Kaul, R. Biorefineries-A Path to Sustainability? Crop Sci. 2010, 50, S-152-S-156. [CrossRef]

12. Keijsers, E.R.P.; Y1lmaz, G.; van Dam, J.E.G. The cellulose resource matrix. Carbohydr. Polym. 2013, 93, 9-21. [CrossRef]

13. Osseweijer, P.; Landeweerd, L.; Pierce, R. Genomics in Industry: Issues of a bio-based economy. Genom. Soc. Policy 2010, 6, 26-39. [CrossRef]

14. Voll, A.; Marquardt, W. Benchmarking of next-generation biofuels from a process perspective. Biofuels Bioprod. Biorefin. 2012, 6, 292-301. [CrossRef]

15. Hoogwijk, M.M. On the Global and Regional Potential of Renewable Energy Sources; Utrecht University: Utrecht, The Netherlands, 2004. 
16. Ministry of Economic Cases. Biomassa 2030-Strategische Visie Voor de Inzet van Biomassa op Weg Naar 2030; MEZ: The Hague, The Netherlands, 2015.

17. Schulze, P.; Holstein, J.; Vlap, H. Biomassapotentieel in Nederland-Verkennende Studie naar vrij Beschikbaar Biomassapotentieel voor Energieopwekking in Nederland; DNV GL: Groningen, The Netherlands, 2017.

18. Tockner, K.; Stanford, J.A. Riverine flood plains: Present state and future trends. Environ. Conserv. 2002, 29, 308-330. [CrossRef]

19. Chaudhary, S.; McGregor, A.; Houston, D.; Chettri, N. The evolution of ecosystem services: A time series and discourse-centered analysis. Environ. Sci. Policy 2015, 54, 25-34. [CrossRef]

20. Finlayson, C.; D'Cruz, R.; Davidson, N.; Alder, J.; Cork, S.; De Groot, R.; Leveque, C.; Milton, G.; Peterson, G.; Pritchard, D.; et al. Ecosystems and Human Well-Being: Wetlands and Water; World Resources Institute: Washington, DC, USA, 2005.

21. De Groot, R.S.; Wilson, M.A.; Boumans, R.M.J. A typology for the classification, description and valuation of ecosystem functions, goods and services. Ecol. Econ. 2002, 41, 393-408. [CrossRef]

22. Grizzetti, B.; Lanzanova, D.; Liquete, C.; Reynaud, A.; Cardoso, A.C. Assessing water ecosystem services for water resource management. Environ. Sci. Policy 2016, 61, 194-203. [CrossRef]

23. Rijkswaterstaat Toelichting op het Onderdeel Vegetatielegger 2014. Available online: http:/ / publicaties. minienm.nl/documenten/vegetatielegger-rijkswaterstaat (accessed on 18 January 2019).

24. Pfau, S.F.; Hanssen, S.V.; Straatsma, M.W.; Koopman, K.R.; Leuven, R.S.E.W.; Huijbregts, M.A.J. Life cycle greenhouse gas benefits or burdens of residual biomass from landscape management. 2019; under review.

25. Dietz, T.; Börner, J.; Förster, J.J.; von Braun, J. Governance of the bioeconomy: A global comparative study of national bioeconomy strategies. Sustainability 2018, 10, 3190. [CrossRef]

26. Bosman, R.; Rotmans, J. Transition governance towards a bioeconomy: A comparison of Finland and The Netherlands. Sustainability 2016, 8, 1017. [CrossRef]

27. Koopman, K.R.; Straatsma, M.W.; Augustijn, D.C.M.; Breure, A.M.; Lenders, H.J.R.; Stax, S.J.; Leuven, R.S.E.W. Quantifying biomass production for assessing ecosystem services of riverine landscapes. Sci. Total Environ. 2018, 624, 1577-1585. [CrossRef]

28. Staatsbosbeheer Passion and Pragmatism-Corporate Plan Staatsbosbeheer 2020; Staatsbosbeheer: Driebergen, The Netherlands, 2015.

29. Creswell, J.W. Research Design-Qualitative, Quantitative, and Mixed Methods Approaches, 2nd ed.; Sage Publications, Inc.: Thousand Oaks, CA, USA, 2003; ISBN 0-7619-2442-6.

30. Faaij, A.P.C. Bio-energy in Europe: Changing technology choices. Energy Policy 2006, 34, 322-342. [CrossRef]

31. Katan, M.B.; Vet, L.E.M.; Rabbinge, R. Visiedocument Biobrandstof en Hout als Energiebronnen. Effect op Uitstoot van Broeikasgassen; KNAW: Amsterdam, The Netherlands, 2015. 